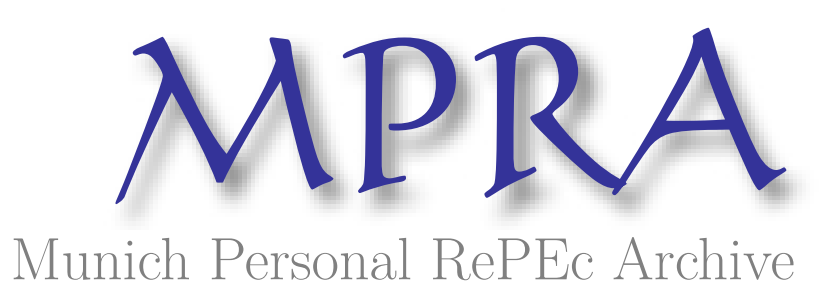

\title{
The Impact of Stagnating Casino Revenues on State and Local Tax Receipts
}

Srinivasan, Arun and Lambert, Thomas

Indiana University Southeast, Northern Kentucky University

2015

Online at https://mpra.ub.uni-muenchen.de/69738/

MPRA Paper No. 69738, posted 27 Feb 2016 09:01 UTC 


\title{
The Impact of Stagnating Casino Revenues on State and Local Tax Receipts
}

\author{
Arun K. Srinivasan ${ }^{1}$ \\ Associate Professor of Economics \\ Indiana University Southeast \\ New Albany, IN 47150 \\ e-mail: asriniva@ius.edu \\ and \\ Thomas E. Lambert \\ Assistant Professor of Public Administration \\ Northern Kentucky University \\ Highland Heights, KY 41099 \\ e-mail: lambertt1@nku.edu
}

\footnotetext{
${ }^{1}$ Corresponding Author. We would like to thank the discussant and participants in 2012 SRSA meetings for their suggestions and comments.
} 


\begin{abstract}
:
In the aftermath of the Great Recession of 2007-2009, the popular press has noted a rebound in casino revenues in some states, and some expect casino revenues to grow and increase again along with any economic recovery. However, before the recent recession, there were trends indicating stagnation or a peak of casino revenues in most states, and as the last recession has indicated, casino revenues were not "recession-proof" as most had thought previously. In fact, casino revenues in most states saw big declines. In this paper, we show that the casino revenues have stagnated or declined partially due to a saturation point being reached with regard to casino gaming in many areas of the United States. The growth rate of casino revenues as well as the tax receipts for the state governments from casinos follows an ' $\mathrm{S}$ ' curve which is similar to a product life cycle curve. The introduction of more gambling venues as well as putting in slot machines at race tracks may give a temporary boost to state gambling tax receipts, but longer run trends indicate that the years of casinos showing large gains in revenues may be over unless casino operations continue to re-invent themselves.
\end{abstract}

JEL Codes: H7, J4, R1

Keywords: Casinos, Tax revenue, Life Cycle Theory, Regional Development. 


\section{Introduction:}

Beginning in the late 1970 s, more than twenty-four state governments in the US have enacted laws permitting legalized casino gambling, racinos (a combination of a casino and race track), state lotteries, electronic gaming devices at bars and entertainment centers, and tribal casinos. Some have written that the increased presence of gambling in different parts of the US comes as a result of more tolerant attitudes toward gambling, the need for states to raise more tax revenues, and local economic development goals and objectives (Madhusudhan 1996, Eadington 1999, Garrett 2003, and Landers 2009). This expansion of gambling occurred in spite of fears about increased crime rates and personal bankruptcies (Friedman, Hakim, and Weinblatt 1989, Hsu 2000) and the cannibalization by casinos of other local hospitality and entertainment operators so that the net impact of a casino could be less than anticipated (Guell 2010).

The casino industry has experienced an explosive growth rate from the late 90's through mid-2000's. As a result, tax receipts from gambling became an important source of revenue for the state and local governments. ${ }^{2}$ Guell (2010) wrote that casinos generate around $\$ 5$ billion annually in tax receipts for state and local (S-L hereafter) jurisdictions on approximately $\$ 30$ billion in casino revenues. Whether the casino industry can sustain this explosive growth and higher revenue in the long run is an issue that needs to be examined. The data on gambling revenue indicate that the trend in casino revenues over the last 20 years has followed an $\mathrm{S}$-curve pattern, which is often observed when goods and services are offered in a market place. The trend or pattern is referred as a "product life cycle" with four stages such as - introductory, growth, maturity and declining stages. Therefore the focus of this paper is to determine whether

\footnotetext{
${ }^{2}$ The gaming commission reports used in the analyses for this paper show that the bulk of the revenues go to the state governments. The local governments usually receive far less amounts. Also, Dadayan and Ward (2011) note that at most gambling tax revenues from lotteries, casinos, race tracks, etc. account for only $2 \%$ of tax revenue.
} 
gambling revenues has been peaking, saturating (maturing) or declining on a per establishment basis, and, to explain the reasons for the stagnating revenues to the state government using long term data for eleven states ${ }^{3}$. We define casino saturation as too many casinos per state and metro region, which in turn results in declining per establishment and overall per state casino adjusted tax revenues and S-L government tax receipts.

\section{Literature review:}

As states have authorized or considered casinos, many authors have evaluated them from different perspectives ranging from social/economic impacts to revenue to S-L governments. Guell (2010) noted that casinos have only a slight impact on employment in communities with high unemployment prior to the casino opening, whereas Garrett (2003) found that casinos have their biggest employment impacts in rural areas. Some have written that casino costs outweigh benefits (Grinols and Mustard 2001) whereas others note inconclusive results in doing an evaluation (Eadington 1999). Walker and Jackson (2007) wrote an article where it was shown that casinos have no real long term economic development impacts on states and localities.

Wenz (2007 and 2008a) found that casinos raise nearby home values and have their greatest impacts in low population density areas and that economic activity was slightly greater in areas with Native American casinos than those with non-Native American casinos, although in general, casinos had very little impact on other quality of life variables. He also failed to find that a proliferation of casinos along the Mississippi River was due to states behaving strategically and trying an import substitution strategy (Wenz 2008b). On the other hand, Navin and Sullivan

\footnotetext{
${ }^{3}$ According to Dadayan and Ward (2011) currently 15 states in the US have legalized corporate commercial casinos. Among them Kansas, Maryland, Pennsylvania and West Virginia legalized gambling in 2007, 2008, 2004 and 2009 respectively. As our focus is to analyze the trend in tax revenues to state government using long run time series data, we exclude these states from our study as they are relatively new. Therefore, we examine 11 states which have gambling records going back to the early to mid-1990s. Tribal casinos have been around for much longer, yet have not played much if any role in the economic development or tax enhancement efforts of state governments over the years. Recently, these establishments have not been making as much money as in the past (Melia 2013).
} 
(2007) showed Illinois and Missouri casinos to be strong competitors in the St. Louis, MissouriIllinois Metropolitan Statistical Area (MSA) after the introduction of Missouri casinos in the mid-1990s to compete against Illinois casinos established on the Illinois side of the Mississippi River earlier in the decade. The competition forced payouts to patrons up, although because of this, tax receipts to state governments went down.

In trying to explain how efficient casinos in five states were in generating gross revenues and S-L tax revenues given inputs such as gaming space, number of employees, etc., Lambert, Srinivasan, Dufrene, and Min (2010) found that those casinos which scored highest in a data envelopment analysis are those that were located in the urban core, central county of a MSA. Whether a casino bordered another state (and thereby can "export" its gambling) was not shown to be a factor in casino efficiency scores, although racinos scored among the best.

After over a decade of casino operations in Indiana, Landers (2009) showed that attendance and revenues at Indiana casinos began to peak around 2003 and 2004 after dramatic growth from 1996 (when casinos were first permitted to operate) to 2002, and this was also the trend in most other states that had casino gaming in the 1990s (Landers 2009, Dadayan and Ward 2011). Landers also noted the negative impact that a tribal casino which opened in southwestern Michigan in 2007 had on a neighboring Michigan City, Indiana casino as well as how the opening of a French Lick, Indiana casino took business away from casinos in Evansville, Indiana and Elizabeth, Indiana, which is in the Louisville, Kentucky-Indiana MSA. Landers concluded that the possibility of legalized gaming in neighboring Kentucky and Ohio could further limit the growth potential of Indiana casinos. In November 2009, Ohio voters approved legalized gaming while Kentucky has continued to debate its merits (Gerth 2010). 
There are a few studies in the literature that have explained the trend in the gambling revenues using a product life cycle approach. According to the product life cycle theory (Anderson \& Zeithaml, 1984), products and services pass through distinct stages through a life cycle. In the introductory stage a product's "life" takes off gradually, and as markets start to accept the product, it shows increasing sales (sometimes at an increasing rate) one time period after another, which marks the growth stage. As time goes by, the rate of sales eventually peaks and slows down as more consumers adopt and use the product until most of the market is covered or saturated, which is referred to as a maturity state. Eventually, if a product is not rejuvenated or repackaged or introduced to a new market segment, and if new competing and alternative products are introduced, a product's sales can go into decline and could eventually become extinct (Kotler and Keller, 2012).

Stansfield (1978) studied the decline of tourism in Atlantic City and identified a four stage resort cycle similar to the product life cycle. The resorts had early success and exclusivity followed by a broad appeal to lower income groups, and then abandonment by early patrons, slow decline, and finally a decay in their popularity. Hofer (1975) suggested that major changes in business strategy are usually required during three stages of the life cycle: introduction, maturity, and decline. During late 1960's when the resorts decayed, Atlantic City sought to reinvent itself by legalizing gambling.

Markusen (1985) and Blair (1995, page 118) write that regional economic success is, to one degree or another, based upon the profitability of the major industries/employers within a region, and this in turn depends upon at which stage these industries find their products in the product life cycle. A disproportionate number of industries/employers in an area which have products in the later stages of the product life cycle will find their profits peaking, which in turn 
means that regional economic performance may also be at a peak unless new and growing industries are developed and nurtured (e.g., Detroit with automobiles, Pittsburgh and Gary, Indiana with steel-making). If not, and if the products go into the decline stage of the product life cycle, regional economic fortunes begin to decline as well (e.g., Flint Michigan, Cleveland, Ohio, etc.). Therefore, states and localities have to continually keep attracting, developing, and/or nurturing new industries in order to keep job and tax revenues growth growing.

Vasche (1985) used a multiple regression analysis to estimate the determinants of percapita lottery sales and found that alternative forms of legal wagering had a negative impact on lottery sales. Deboor (1986), used an exponential growth model to report that since 1971 lottery sales had grown rapidly due to new adoption and the spread of participation in the lottery states. He projected that sales of lottery would level off in the future. Mikesell and Zorn (1987) validated earlier works of Vasche and DeBoer on lottery sales and reported that lottery sales begin to decline after approximately 11 years due to alternative wagering and competition (border effects) from surrounding states selling lotteries.

Moss et.al., (2003) used a Butler S product life cycle to explain gaming revenue in Mississippi. From their empirical analysis, they report that the casino industry in Mississippi followed a Butler's S-shaped product life cycle curve, and that revenues are near the end of the mature stage (Stage 5) or possibly even at the onset of decline (stage 6). They conclude that increased competition among casinos within the state and from other states has resulted in a reduction in the gamblers/customer base and overall growth in the industry during the later period.

The rest of the paper proceeds as follows: In the next section, the methods used to assess trends in casino gambling revenues per establishment are discussed followed by the results and a 
discussion of the findings. In the last section, we discuss any limitations of the research and policy recommendations with regard to S-L casino gambling for both states that currently have casinos as well as those considering the legalization of casino gambling.

\section{Model:}

The data are analyzed using a simple tabular/graphical analysis and regression analysis using an exponential growth forecasting model. For the tabular analysis (see Tables 1 and 2) we use data for eleven states from 2000 to 2010 collected from annual reports for the gaming industry from each state. The 11 states were chosen because they form a panel of states that show casino revenues rising and then declining in the last decade. The growth rate of tax revenue from casinos is computed on an annual basis to determine the trend.

The tax receipts (nominal) for S-L governments from casinos may be explained using the number of casinos in a state, rate of unemployment, real state product, tax rates ${ }^{4}$, number of slot machines, number of tables, dummy variable for recessionary years, and the time (in years) that casinos have been in place. The growth of tax receipts for S-L governments follows an exponential growth during initial years and then it plateaus during later years. To explain this growth, our growth function takes an exponential form

$$
U=a e^{o k t}
$$

where, $\mathrm{U}$ is the tax receipts to state governments, $t$ is the time trend, $k$ is number of establishments. This growth function is extended to include other variables and converted to semi-logarithmic specification and the regression is conducted in the following manner:

\footnotetext{
${ }^{4}$ This was used in a subset of models because not all of the states disclosed their state and local tax rates or it was difficult to determine their tax rates for casinos. Yet four of the larger states (Illinois, Indiana, Missouri, and Iowa) disclosed this information, and so this was variable was used with the others to gauge the effects of tax rates on tax revenue collected.
} 
$\log ($ tax receipts $)=a+b_{1}($ establishments $)+b_{2}($ unemployment rate $)+b_{3} \log ($ per capita real $G D P)+b_{4} \log$ tax rates $+b_{5} \log$ slot machines $+b_{6} \log$ tables $+b_{7}($ recession dummy) $+b_{8}($ year $)$.

where, tax receipts are total tax receipts to the S-L governments from casinos, number of establishments in a given year (both in linear and quadratic forms), rate of unemployment in a state in time $t$, per-capita real state production in time $t$, and year (in linear, quadratic and cubic forms $)$ is a time trend $(1991=0 \ldots ., 2010=19)$. Unemployment rate and per-capita real state product are used to measure the economic well-being of states. These variables indirectly measure the discretionary spending of people. The number of slots and tables are used to see if the level of gambling opportunities impacts tax receipts, while the tax rates are used to determine the impact on tax S-L government tax receipts. The dummy recessionary variable is used to control for the effects of any economic downturns in the economy and their possible impacts on revenues. For four of the larger of the eleven states (Illinois, Indiana, Missouri, and Iowa), average tax rates were calculated from state reports and used to see if higher rates yield higher revenues. ${ }^{5}$ The estimated coefficients are elasticities of tax receipts with respect to real state product, number of slots and tables, and tax rates. The estimated coefficient of the unemployment rate (which is not in log form) is interpreted as the percentage change in the tax receipts when the percentage of unemployment rate increases by one percentage point, ceteris paribus (Wooldridge, 2002). Time trend is the growth rate of nominal tax receipts for S-L governments every year.

\section{(Insert Tables 1 and 2 around here)}

\section{Data:}

\footnotetext{
${ }^{5}$ Because of the possible endogeneity between tax revenues and tax rates, 2SLS regression was performed using winnings to patrons (WTP) or winning per admissions as an instrumental variable. WTP was chosen as an instrumental variable since greater payments to patrons result in less tax revenues and adjusted gross revenues to casinos since greater winnings paid out leave less money for taxes and casino earnings. (Navin and Sullivan 2007).
} 
The annual data for the 11 states for the last 20 years (1991-2010) were collected from annual reports for the gaming industry from various states. In 1991, 7 states in the US had granted licenses for commercial casino operations and subsequently Missouri started granting licenses in 1994, Indiana in 1996, and Michigan in 1997 (see Table 1 for number of casinos). The data collected at the state level includes tax revenue for the S-L government (tax receipts) from the casinos, adjusted gross revenues, number of establishments (we include only the number of casinos operating in a state), unemployment rates, per-capita gross domestic product (nominal) and number of casinos surrounding a particular state to analyze the border effect. Only in a handful of states were casinos allowed to operate during the 1990's. By 1998, all eleven states in our study had fully operational casinos. Therefore we have an unbalanced panel data for the analysis with 202 observations for 20 years. Additionally, for a subset of 7 states (Colorado, Indiana, Illinois, Iowa, Mississippi, Missouri and South Dakota) we collect annual number of tables and slots in casinos from 1995 through 2010. Finally, among the seven states, we collect annual average tax rates for four states (Colorado, Indiana, Illinois and Iowa), for the same time period. More states would have been used, but the data for tables, slots, and tax rates were not available for all states.

\section{Results and Discussion:}

\section{(Insert Figures 1 and 2 around here)}

Data for eleven states (see Table 2 for a list) which have had casinos (whether riverboat or regular casinos) as well as racinos for the period of 1991 to 2010 are examined as a cohort to see whether casino gross revenues and casino revenue shares paid to the states and local governments, which grew rapidly during the 1990s, had peaked and/or even declined during the following decade similar to what was noted above about Indiana. Of special interest is whether 
on a per establishment basis revenues have peaked or declined, which would possibly indicate that a saturation point has been reached in casino revenue growth due to more and more establishments operating over time.

In looking at Table 2, which like the other tables in this paper uses fiscal year (July 1 to June 30) numbers, the first few years of the decade showed on a per establishment basis a good average growth rate of almost 12.8 , yet afterwards, growth slowed from the middle of the decade up to the onset of the Great Recession (around a 3-4 percent growth rate), and then during and after the recession, growth was at its lowest, with the only good year being 2009-10. At a more aggregate level, Figure 1 shows overall casino revenues for most states either flat-lining or declining by the middle of the decade before the recession started ${ }^{6}$, and Figure 2 illustrates the volatility in revenue growth changes from year to year on a per establishment basis. The trend in the casino revenues during these 10 years or so somewhat resembles the latter stages of Butler's S-curve pattern or a product life cycle. Meanwhile, the total monthly revenues for five states which had data going back to the 1990s (excluding Nevada) —Colorado, Illinois, Indiana, Mississippi and Missouri-form an S-shaped curve similar to a product life cycle curve (see Figure 3). ${ }^{7}$

\section{(Insert Table 3, Figures 3 and 4 around here)}

Table 3 and Figures 3 and 4 show most tax revenues to state and local governments from casino operations also peaking or declining around the middle of the 2000-2010 time period with revenue growth rates doing better earlier in the decade than later. The stagnating or declining revenues occur even as some states like Indiana and Louisiana examined in this paper have

\footnotetext{
${ }^{6}$ Mississippi casinos in the Biloxi-Gulfport metro area suffered a setback with Hurricane Katrina, which explains a sudden decrease for this state in the middle of the decade, although gambling revenues have struggled to get past their 2004 peak.

${ }^{7}$ Not all states disclose or publish data on a monthly basis.
} 
begun to allow gambling at race tracks during the decade (Iowa has had racinos since the 1990s). In order to keep revenues from stagnating or falling, states which previously only had riverboat gaming changed their laws to allow land based gaming in order to increase attendance and revenues (e.g., Illinois and Indiana) or permitted gambling at race tracks (e.g., Indiana and Louisiana among others). This paper puts forth that casino revenues are now probably at the maturity stage of the product life cycle and offers models to support this contention.

\section{(Insert Table 4 around here)}

The growth function in semi-logarithmic specification for the panel data (across states over time $[1991-2010]^{8}$ ) was estimated using a fixed effects model with state fixed effects ${ }^{9}$ and is presented in Table 4. Results in the first column indicate that establishment and establishment squared are not statistically significant. In the second and third columns, establishment squared is statistically significant $(\alpha<0.10)$ and has a negative coefficient. Therefore there is a little evidence that revenues may increase, peak, and then decline over time. Per-capita real state domestic product has a positive and significant relationship with tax receipts in the first model (column 1) but is not statistically significant in the others. The recession dummy is not significant in all three specifications, although the unemployment rate variable works in all three models at an alpha value of below $10 \%$ and has a negative coefficient. Therefore, cyclical effects matter with casino tax revenues. But the most interesting results in these specifications are the estimated coefficients on the year variables. In the first specification, the year variable is positive and significant, illustrating that the tax revenues for S-L governments are growing every year for all states in the model. To determine whether the tax revenue for states has stagnated or

\footnotetext{
${ }^{8}$ We also analyzed a balanced panel data [1998 - 2010] for all eleven states, and these results are reported in Table1 in the Appendix. The results are statistically similar to the results obtained from an unbalanced panel.

${ }^{9}$ Hausman tests showed that fixed effects results are preferred to random effects or pooled OLS models, so those are shown in this paper. Hausman test and results from random effect models can be sent upon request.
} 
declined, a quadratic and cubic terms are introduced in the next two specifications. In the second specification, the quadratic term (year) is significant and negative, indicating that the growth rate of tax receipts to state and local governments has started to decline in the later years and follows a 'S shaped" trend or pattern like the latter stages of a product life cycle ${ }^{10}$. The third specification in which there are quadratic and cubic year terms does not have these variables showing statistical significance.

\section{(Insert Table 5 around here)}

The growth function of tax revenues was estimated by including games - slots and tables in the semi-log specification for 7 states $^{11}$ in the state fixed effect model. The results in Table 5 columns 1 to 3 indicate that adding tables and slots did not have that much of an impact on adding more tax revenues. The recession dummy is not statistically significant in any of the models, whereas the state domestic product per capita is only statistically significant in the first model (column 1). In these models the unemployment rate is not statistically significant. The other results in Table 5 column (2) and (3) contain quadratic and cubic specifications for the year variable. The year variables in quadratic specification (column 2) are significant with a positive sign for year and negative sign for the squared term, illustrating a decline in tax revenues for S-L governments. In the cubic specification, only the year variable is significant. In models 1 and 3 (columns 1 and 3), the number of establishments and/or establishments squared were the other variables that were statistically significant implying a direct relationship between number of casinos in a state and tax revenue. In the first model, the increase and then decline in S-L

\footnotetext{
${ }^{10}$ The results were statistically similar when we controlled for number of Native American casinos in this specification. Native American casinos had a negative and significant effect on tax receipts to the state governments. The payout to patrons from Native American casinos is relatively more than other casinos in the state as they pay an average of 10-12 percent of revenue to the state government while commercial casinos pay 19-24 percent of total gaming revenue (National Indian Gaming Commission). The results from this specification are presented in Appendix - Table 1.

${ }^{11}$ Colorado, Indiana, Illinois, Iowa, Mississippi, Missouri and South Dakota
} 
revenue is denoted by the statistical significance of the establishment and squared establishment terms.

\section{(Insert Table 6 around here)}

A third specification for tax revenues was estimated by including average tax rate paid by the casinos to the S-L governments. This specification was analyzed for a subset of four states ${ }^{12}$. The results from all three specifications presented in Table 6 indicate that the tax rates have a negative and significant influence on the tax revenue. The third-order polynomial specification in column (3) indicates that higher GDP and lower unemployment rates have a significant and positive effect on the tax revenues, while the higher tax rates reduces tax revenues to the state and local governments. All three year variables (first, second and third order) are significant and exhibit an S-curve configuration. These results indicate that growth of tax revenue for S-L governments started to decline in later years and follows a pattern similar to a product life cycle. During the 1990's and up to the early part of the last decade, there was high growth in overall casino revenues as well as in what was paid in taxes to S-L governments throughout the US (with perhaps the exceptions of a downturns due to the 1991 and 2001 recessions). After the 2001 recession, the revenue for casinos slowed down or started to experience decline as the casinos had to share their customer base with new gaming options (within their borders and with neighboring states). To prevent revenues from stagnating or falling, states which previously only had riverboat gaming changed their laws to allow land based gaming in order to increase attendance and revenues (e.g., Illinois and Indiana) or permitted gambling at race tracks (e.g., Indiana and Louisiana among others). These efforts are similar to manufacturers "re-positioning" or "re-packaging" a product so as to keep sales from stagnating or to reach broader markets, such

\footnotetext{
${ }^{12}$ Illinois, Indiana, Iowa, and Missouri.
} 
as the introduction of iPhones and smart phones as improvements over cell phones, or the introduction of HDTV to replace traditional television sets.

\section{(Insert table 7 around here)}

However, it is possible to look at the situation that Illinois faced after Indiana casinos opened and look at the St. Louis area casino situation. Table 7 shows total Illinois casino revenues and proceeds to the state from 1991 to 2010. The introduction of casinos in Missouri did not really impact the growth of casino revenues in 1994 negatively although it did slow the gains in casino revenues, and with the introduction of casinos in full swing in Indiana in 1996, Illinois casino revenues went into a brief decline until 1998, but thereafter showed gains until 2006. Beginning in 1999, Illinois allowed "dockside" gambling at its riverboats, which led to a big rebound in casino revenues that year, although Indiana followed suit not long afterwards (Illinois Gaming Board and Indiana Gaming Commission Annual Reports). Increasing the access to gambling venues has been a recurring theme of the casinos in different states in order to try stay competitive with neighboring states and in order to keep revenues growing.

\section{(Insert Table 8 around here)}

Further exploring whether the opening of new casinos in surrounding states have an impact on tax revenue to S-L governments (or "border effects"), we looked at Illinois again by using regression analysis. Again, Illinois was one of the few states that operated casinos in the early 1990s. After that several Midwest states jumped on the bandwagon in granting licenses to run casinos - Iowa, Missouri (1994) and Indiana (1995). To analyze this border effect on Illinois, we use the annual tax receipts data from 1991 through 2010 for Illinois, and regression equations are estimated including number of casinos in Iowa (Iowa had casinos in operation in 1989) in the model followed by Missouri and Indiana. The results from these three models are presented in 
Table 6. In all three specifications, the number of establishments and Illinois real state GDP percapita were positive and had a significant influence on tax revenue to Illinois. The magnitude of the estimated coefficients for the establishment variable, decreased when Missouri granted licenses to open casinos (5.7325 to 5.3590), and it bounced back by $1 / 11^{\text {th }}$ of a percent (5.4431) when Indiana granted licenses to open casinos. In all three regressions the effect of the state variable is significant as Illinois did experience a slight dip in the tax revenues after Missouri granted licenses to operate casinos and it recovered slightly after Indiana started casinos. The estimated coefficient on per-capita GDP declines as more states are included in the regression. The tax receipts on Illinois declined by half when Missouri granted license to operate casinos and there was a marginal decline when Indiana followed suit in 1995. The tax revenues for Illinois rebounded after the introduction of dockside gambling on river boats in 1999. From this analysis, we could interpret that decreases in revenues for Illinois are due to the opening of casinos in Missouri and Indiana as "border effects." We expected that the state variables Iowa, Missouri and Indiana would have a negative impact of Illinois's tax receipt which could possibly explain the border effects. Unfortunately, our analysis did not yield those results. A future study could be conducted specifically to analyze the border effect by collecting the data at a micro (casino) level to estimate the "border effects", similar to other studies that looked at the St. Louis and Chicago areas.

On the other hand, perhaps the product life cycle approach to explaining the peak in or plateauing of casino revenues carries more weight than possible border effects because it may not be how many casinos there are in a region but the popularity of casino gaming that is driving revenues and attendance. When casinos were still fairly new in Illinois in the 1990s, the competition from Missouri and Illinois was not a real hindrance because the customer base was 
still growing since casinos in these states were still in their "growth stage" of the product life cycle. If all revenues are stagnating or peaking in most of these states, regardless of whether it shares a border with a state that also has casinos, then this paper believes that the stagnation in casino revenues may mostly be due to a saturation point being reached among the casino customer base within and among the states, which would correspond to the maturity stage of a product life cycle.

\section{Conclusion:}

In this study, we analyzed the stagnating casino revenues and tax receipts for the eleven states using a panel data from 1991 - 2010. Our analyses indicate that tax receipts for state governments followed an S-shaped growth pattern with higher growth rate during the decade of 1990's followed by a much slower growth rate in the last decade. The "border effect" on Illinois with the number of casinos operating in the neighboring states of Iowa, Missouri and Indiana was evident with decreases in tax receipts for Illinois from its existing establishments within the state for certain years. However, in the aggregate and over a longer period of time, any border effects did not seem to matter, similar to the findings of Lambert, Srinivasan, Dufrene and Min (2010).

With revenues apparently stagnating, even during a recovery stage in the current business cycle (as of mid-2013), and with more states legalizing or thinking about legalizing gambling, the casino industry in the US faces the challenge of how it can once again "re-invent" or reposition itself to prevent a decline in future revenues or market share. Another option may be for the casinos to ask for assistance from the states in which they operate - the state of Indiana recently gave tax breaks to its casinos in order to help them deal with new competition from casinos in Ohio (Cook 2013). Our results indicate that the casino industry in the US may be in the maturity stage of the product life cycle. With online gaming currently being debated in the 
US, one has to wonder whether physical gambling venues offer as much promise in the future as they did in the past. Unless casino firms are able to offer more and better entertainment or other features to draw in consumers, the traditional casino organizational arrangement could be faced with declines in sales into the foreseeable future, which would mean less tax revenues to the states, unless states are able to somehow tap into any revenues from possible legalized sports gambling and/or online gambling, which could also mean opening up investment from foreign gambling operations which already have an online presence (Parry 2011). Many states want possible tax revenues from online gaming, even though it may require state regulation and strict monitoring. In 2011 the New Jersey legislature passed a bill to legalize online gaming within the state but Governor Chris Christie vetoed it. However, that November, New Jersey voters approved a referendum legalizing gambling, and although any attempt to implement the law was thought to receive a challenge by the federal government (Shafer 2011), those fears have now passed, and New Jersey and Delaware are expected to offer online gaming within their borders before the end of 2013 (Parry 2013) ${ }^{13}$. The news for New Jersey is especially welcomed given the closing of four major casinos in Atlantic City in 2014 with one costing \$2.4 billion in existence for only two years (Chappell 2014). A major concern with online gambling is how to minimize illegal gambling and interstate gambling (within state online gaming is legal), which may necessitate the need for cyber café-like gaming parlors. Of course, any boost in tax revenues from online gambling could be offset by the loss of jobs in actual casinos located in the states - online gambling can be offered from anywhere and is not as labor intensive as regular casino gambling. This would possibly blunt the economic development efforts of casinos, unless

\footnotetext{
${ }^{13}$ The federal government now no longer opposes internet gaming as long as it does not include gambling on sports events.
} 
casino employees could somehow be re-assigned to new duties in online betting parlors if online gaming is not permitted from one's home. 


\section{References:}

Anderson, Carl A, and Zeithaml, Carl P. 1984. "Stage of the Product Life Cycle, Business Strategy, and Business Performance.” Academy of Management Journal, 27 (1): 5-24.

Associated Press. 2010. "Atlantic city faces more pressure as casino opens in Philadelphia." September 24, 2010. http://www.nj.com/business/index.ssf/2010/09/atlantic_city_faces_more_press.html Retrieved on February 28, 2012.

Blair, John P. 1995. Local Economic Development: Analysis and Practice. Thousand Oaks, CA: Sage Publications.

Chappell, Bill. 2014. “After Just Two Years, Huge Atlantic City Casino Shuts Down,” npr.org. http://www.npr.org/blogs/thetwo-way/2014/09/02/345188028/after-two-years-huge-atlantic-citycasino-shuts-down . Retrieved on February 22, 2015.

Cook, Tony. 2013. "New Casino Tax Break Costs Indiana Millions." The Indianapolis Star. June 11, 2013. http://www.indystar.com/article/20130611/NEWS/306110028/New-casino-taxbreak-costs-Indiana-millions?nclick_check=1. Retrieved on June 23, 2013.

Dadayan, Lucy and Robert B. Ward. 2011.. 'Back in the Black: States' Gambling Revenues Rose in 2010." Published by the Nelson A. Rockefeller Institute of Government. June 23, 2011.

DeBoer, Larry. 1986. "When will State Lottery Sales Growth Slow?” Growth and Change, 17: 28-36.

Eadington, William R. 1999. "The Economics of Casino Gambling," Journal of Economic Perspectives, 13(3): 173-192.

Friedman, Joseph, Simon Hakim, and J Weinblatt. 1989. "Casino Gambling as a 'Growth Pole' Strategy and Its Effect on Crime," Journal of Regional Science, 29(4): 615-623.

Garrett, Thomas A. 2003. "Casino Gambling in America and its Economic Impacts," Federal Reserve Bank of St. Louis Report, August 2003, http://stlouisfed.org/community_development/assets/pdf/CasinoGambling.pdf . Retrieved on February 9, 2010.

Gerth, Joe. 2010. "Kentucky Support Grows for Slot Machines." The Courier-Journal, February 3, pages A1, A4.

Grinols, Earl L. and David B. Mustard. 2001. "Business Profitability Versus Social Profitability: Evaluating Industries with Externalities, the Case of Casinos," Managerial and Decision Economics, 22: 143-162.

Guell, Robert C. 2010. "Chapter 43: The Economic Impact of Casino Gambling," Issues in Economics Today, $5^{\text {th }}$ Edition, McGraw-Hill Publishers. New York, New York. 
Hofer, C.W. 1975, "Toward a Contingency Theory of Business Strategy," Academy of Management Journal, 18: 744-810.

Hsu, Cathy H. C. 2000. "Residents' Support for Legalized Gaming and Perceived Impacts of Riverboat Casinos: Changes in Five Years," Journal of Travel Research, 38(4): 390-395.

Illinois Gaming Board. Annual Reports. http://www.igb.state.il.us/annualreport/. Accessed on February 15, 2010.

Indiana Gaming Commission. Annual Reports. http://www.in.gov/igc/. Accessed on February $15,2010$.

Iowa Racing and Gaming Commission. Annual Reports. http://www.iowa.gov/irgc/. Accessed on February 15, 2010.

Kotter, Philip, and Keller, Kevin L, 2012, Marketing Management, $14^{\text {th }}$ Edition. Upper Saddle River, New Jersey: Prentice Hall.

Lambert, Thomas E., Arun K. Srinivasan., Uric B. Dufrene., and Hokey Min. 2010. "Urban Location and the Success of Casinos in Five States." International Journal of Management and Marketing Research, 3(3): 1-16.

Landers, Jim. 2009. “The Two-Sided Coin: Casino Gaming and Casino Tax Revenue in Indiana" and "Future Casino Tax Yields: What Recent Trends in Casino Wagering and Attendance Suggest," Indiana Business Review, Spring 2009, pages 1-6 and 7-13.

Louisiana Gaming Control Board. Annual Reports. http://lgcb.dps.louisiana.gov/. Accessed on February 15, 2010.

Madhusudhan, Ranjana G. 1996. "Betting on Casino Revenues: Lessons from State Experiences," National Tax Journal, 49(3): 401-412.

Markusen, Anne R. 1985. Profit Cycles, Oligopoly, and Regional Development. Cambridge, MA: MIT Press.

Melia, Michael. 2013. "As casinos struggle, tribes seek more federal aid." Associated Press. March 25, 2013. http://www.lasvegassun.com/news/2013/mar/25/casinos-struggle-tribes-seekmore-federal-aid/ Retrieved on June 7, 2014.

Mikesell, J.L., and Zorn, C.K. 1987. "State Lottery Sales: Separating the Influence of Marketsadn Game Structure," Growth and Change, 18: 10-19.

Mississippi Gaming Commission. Annual Reports. http://www.mgc.state.ms.us/. Accessed on February 15, 2010. 
Missouri Gaming Commission. Annual Reports. http://www.mgc.dps.mo.gov/ . Accessed on February 15, 2010.

Moss, Steven E, Ryan Chuck, and Wagoner, Charles B. 2003. "An Empirical Test of Butler's Resort Product Life Cycle: Forecasting Casino Winnings," Journal of Travel Research, 41: 393399.

National Indian Gaming Commission. http://www.nigc.gov/ Retrieved on June 7, 2014.

Navin, John C., and Timothy S. Sullivan. 2007. Do Riverboat Casinos Act as Competitors? A Look at the St. Louis Market. Economic Development Quarterly 21(1):49-59.

Parry, Wayne. 2011. "Casino gambling's future is online, industry panel says," Huffington Post, May 4, 2011. http://www.huffingtonpost.com/2011/05/24/casino-online-future_n_866529.html. Retrieved on November 13, 2012.

. 2013. "US Casinos Brace for Effect of Internet Gambling." May 5, 2013. Associated Press. http://news.msn.com/us/casinos-brace-for-impact-of-internet-gambling . Retrieved on June 23, 2013.

Shafer, Seth. 2011. "New Jersey Voters Say Yes to Sports Betting", Casino Top 10, November 12, 2011. http://www.casinotop10.net/New-Jersey-Voters-Say-Yes-to-Sports-Betting Retrieved on November 13, 2012.

Stansfield, C. 1978. "Atlantic City and the Resort Cycle: Background to the Legislation of Gambling," Annals of Tourism Research, 5:238-51.

State Casino Taxes, 2004. National Conference of State Legislators http://www.ncsl.org/issues-research/econ/state-casino-taxes.aspx accessed on November 1st 2012.

Vashce, J. D. 1985. “Are Taxes on Lotteries Too High?” Journal of Policy Analysis and Management, 4(2): 269-271.

Walker, Douglas M. and Jackson, John D. 2007. "Economic Development and Casinos: Do Casinos Cause Economic Growth?" American Journal of Economics and Sociology, Vol. 66, No. 3 (July, 2007).

Wenz, Michael. 2007. "The Impact of Casino Gambling on Housing Markets," Journal of Gambling Business and Economics, 2007, 1(2):101-120.

of Regional Science. 2008a. "Matching Estimation, Casino Gambling and Quality of Life." Annals . 2008b. "The Spatial Evolution of Casino Gambling," Cityscape: A Journal of Policy Development and Research, 10(3): 203-228. 
Wooldridge, Jeffery M. 2002. Introductory Econometrics: A Modern Approach, $2^{\text {nd }}$ Edition, Mason, Ohio: Thomson South-Western. 
Table 1: Number of establishments (Casinos).

\begin{tabular}{|c|c|c|c|c|c|c|c|c|c|c|c|c|c|c|c|c|c|c|c|c|}
\hline State & 1991 & 1992 & 1993 & 1994 & 1995 & 1996 & 1997 & 1998 & 1999 & 2000 & 2001 & 2002 & 2003 & 2004 & 2005 & 2006 & 2007 & 2008 & 2009 & 2010 \\
\hline Colorado & 40 & 65 & 60 & 58 & 57 & 54 & 49 & 48 & 45 & 43 & 43 & 44 & 45 & 47 & 46 & 43 & 41 & 40 & 39 & 39 \\
\hline Illinois & 5 & 9 & 10 & 10 & 10 & 10 & 9 & 9 & 9 & 9 & 9 & 9 & 9 & 9 & 9 & 9 & 9 & 9 & 9 & 9 \\
\hline Indiana & 0 & 0 & 0 & 0 & 6 & 9 & 9 & 10 & 10 & 10 & 10 & 10 & 12 & 12 & 12 & 11 & 13 & 12 & 11 & 11 \\
\hline Iowa & 0 & 0 & 0 & 0 & 6 & 9 & 9 & 10 & 10 & 10 & 10 & 10 & 12 & 12 & 12 & 11 & 13 & 12 & 11 & 11 \\
\hline Louisiana & 0 & 0 & 0 & 6 & 7 & 11 & 11 & 11 & 23 & 24 & 28 & 20 & 14 & 28 & 27 & 27 & 18 & 19 & 14 & 14 \\
\hline Michigan & 0 & 0 & 0 & 0 & 0 & 0 & 0 & 3 & 3 & 3 & 3 & 3 & 3 & 3 & 3 & 3 & 3 & 3 & 3 & 3 \\
\hline Mississippi & 0 & 0 & 11 & 11 & 11 & 13 & 15 & 15 & 35 & 21 & 36 & 33 & 33 & 31 & 33 & 31 & 34 & 34 & 30 & 30 \\
\hline Missouri & 0 & 0 & 4 & 4 & 6 & 7 & 11 & 11 & 11 & 13 & 16 & 12 & 13 & 15 & 14 & 12 & 15 & 16 & 12 & 12 \\
\hline Nevada & 192 & 186 & 207 & 207 & 213 & 229 & 235 & 235 & 238 & 321 & 325 & 248 & 263 & 259 & 269 & 264 & 209 & 204 & 256 & 270 \\
\hline New Jersey & 12 & 12 & 12 & 12 & 12 & 12 & 12 & 12 & 13 & 13 & 15 & 12 & 13 & 14 & 17 & 14 & 13 & 15 & 11 & 11 \\
\hline $\begin{array}{l}\text { South } \\
\text { Dakota }\end{array}$ & 79 & 80 & 83 & 87 & 94 & 98 & 91 & 89 & 92 & 95 & 108 & 112 & 113 & 116 & 123 & 138 & 139 & 137 & 138 & 140 \\
\hline
\end{tabular}

Source: Dadayan and Ward and state gaming commission reports. 
Table 2: Casino gross revenues percentage change per establishment per year.

\begin{tabular}{|c|c|c|c|c|c|c|c|c|c|c|}
\hline & 2000-01 & 2001-02 & 2002-03 & 2003-04 & 2004-05 & 2005-06 & 2006-07 & 2007-08 & 2008-09 & 2009-10 \\
\hline Colorado & 7.1 & 68.1 & -8.4 & 0.5 & 4.6 & 12.3 & 1.3 & -15.6 & 36.1 & -29.1 \\
\hline Illinois & 16.6 & -5.2 & 34.8 & 0.5 & 4.7 & 6.9 & -22.7 & -20.9 & -0.6 & 20.1 \\
\hline Indiana & 9.1 & 11.9 & 4.7 & -11.1 & 4.5 & 3.2 & 12.9 & -12.3 & 13.8 & 8.5 \\
\hline Iowa & 11.5 & 2.9 & 4.4 & 10.0 & -23.1 & 5.6 & 27.1 & -8.2 & -1.5 & 29.2 \\
\hline Louisiana & 8.6 & -7.2 & 43.8 & 42.5 & -44.5 & 11.3 & 6.8 & 53.6 & -7.7 & 26.4 \\
\hline Michigan & -9.7 & 49.0 & 13.0 & 5.2 & -8.2 & -20.4 & 36.6 & -8.3 & -1.5 & 2.9 \\
\hline Mississippi & 69.9 & -41.3 & 8.4 & 2.9 & -5.4 & -2.2 & 19.7 & -14.2 & -9.4 & 9.9 \\
\hline Missouri & -9.2 & -6.1 & 43.5 & -0.7 & -6.8 & 11.5 & 18.9 & -18.2 & -2.4 & 36.8 \\
\hline Nevada & 1.4 & -5.2 & 1.1 & 8.1 & 5.0 & 10.3 & 6.4 & 0.5 & -9.9 & -3.8 \\
\hline New Jersey & 0.0 & -11.8 & 28.0 & -1.1 & -3.1 & -14.4 & 14.5 & -0.5 & -24.8 & 30.7 \\
\hline South Dakota & 6.0 & 2.0 & 29.5 & -1.0 & 16.6 & 27.7 & -5.7 & 156.0 & -16.2 & -13.1 \\
\hline $\begin{array}{l}\text { Average } \\
\text { Average } 2000-01 \\
\text { to 2003-04 } \\
\text { Average } 2004-05 \\
\text { to 2006-07 } \\
\text { Average } 2007-08 \\
\text { to 2009-10 }\end{array}$ & 10.12 & 5.21 & 18.44 & $\begin{array}{r}5.07 \\
12.81\end{array}$ & -5.05 & 4.70 & 10.54 & 10.17 & -2.19 & 10.76 \\
\hline
\end{tabular}

Source: Dadayan and Ward and state gaming commission reports. 
Table 3: State and local tax revenue percentage change per establishment per year.

\begin{tabular}{|c|c|c|c|c|c|c|c|c|c|c|}
\hline & 2000-01 & 2001-02 & 2002-03 & 2003-04 & 2004-05 & $2005-06$ & 2006-07 & 2007-08 & 2008-09 & $2009-10$ \\
\hline Colorado & 13.67 & 66.74 & -6.61 & 1.03 & 0.61 & 16.80 & 2.46 & -15.78 & 31.56 & -26.03 \\
\hline Illinois & 18.80 & -0.27 & 72.76 & 12.34 & 6.54 & -2.18 & -23.27 & -14.71 & -16.85 & 10.92 \\
\hline Indiana & 5.71 & 9.15 & 30.67 & -7.78 & 4.42 & 3.65 & 15.65 & -19.27 & 2.40 & 24.02 \\
\hline Iowa & 10.87 & 9.57 & 4.88 & 15.69 & -18.55 & -3.56 & 28.83 & -1.08 & 6.92 & 14.51 \\
\hline Louisiana & 10.04 & -11.56 & 40.46 & 43.98 & -48.98 & 16.21 & 2.75 & 53.57 & -8.59 & 25.33 \\
\hline Michigan & -5.50 & 61.93 & 11.78 & 8.47 & 17.33 & -20.02 & 36.66 & -18.88 & -5.93 & 23.13 \\
\hline Mississippi & 69.85 & -40.41 & 9.76 & 0.85 & 7.22 & -23.19 & 29.29 & -5.45 & -9.43 & 4.22 \\
\hline Missouri & -12.03 & -9.28 & 42.43 & -1.75 & -8.00 & 10.09 & 16.80 & -18.81 & -0.10 & 38.68 \\
\hline Nevada & 2.76 & -3.34 & 32.93 & 11.63 & 7.45 & 6.74 & 5.38 & 19.42 & -10.31 & -20.78 \\
\hline New Jersey & 0.69 & -11.42 & 24.38 & 0.55 & -4.46 & -12.48 & 20.41 & 0.46 & -25.52 & -10.86 \\
\hline South Dakota & -0.17 & 8.96 & 25.60 & -5.05 & 14.09 & 23.55 & 0.55 & 167.79 & -19.35 & -13.98 \\
\hline $\begin{array}{l}\text { Average } \\
\text { Average } 2000-2001 \\
\text { to } 2003-2004 \\
\text { Average } 2004-2005 \\
\text { to } 2006-2007 \\
\text { Average } 2007-2008 \\
\text { to } 2009-2010\end{array}$ & 10.43 & 7.28 & 26.28 & $\begin{array}{r}7.27 \\
12.81\end{array}$ & -2.03 & 1.42 & 12.32 & 13.39 & -5.02 & 4.88 \\
\hline
\end{tabular}

Source: Dadayan and Ward and state gaming commission reports. 
Table 4: Estimated growth/forecasted model for tax receipts (1991-2010) using fixed effect (state) in semi-log specification.

\begin{tabular}{|c|c|c|c|}
\hline Variable & $\begin{array}{c}\text { Fixed Effect } \\
\text { (State) (1) }\end{array}$ & $\begin{array}{c}\text { Fixed Effect } \\
\text { (State) (2) }\end{array}$ & $\begin{array}{c}\text { Fixed Effect } \\
\text { (State) (3) }\end{array}$ \\
\hline Establishment & $\begin{array}{c}0.0058 \\
(0.0059)\end{array}$ & $\begin{array}{l}0.0068 \\
(0.006)\end{array}$ & $\begin{array}{c}0.0069 \\
(0.0058)\end{array}$ \\
\hline Establishment Squared & $\begin{array}{l}-.00002 \\
(.00001)\end{array}$ & $\begin{array}{c}-0.00002 * \\
(0.0000)\end{array}$ & $\begin{array}{l}-0.00002 * \\
(0.00001)\end{array}$ \\
\hline Unemployment Rate $^{+}$ & $\begin{array}{l}-0.0352^{*} \\
(0.0209)\end{array}$ & $\begin{array}{l}-0.0365^{*} \\
(0.0201)\end{array}$ & $\begin{array}{c}-0.0363 * \\
(0.0202)\end{array}$ \\
\hline Real State Product & $1.3116^{* * *}$ & -0.1776 & -0.1446 \\
\hline Per-capita & $(0.3512)$ & $(0.5167)$ & $(0.5374)$ \\
\hline Recession Dummy & $\begin{array}{c}-0.0761 \\
(.0856)\end{array}$ & $\begin{array}{l}-0.0038 \\
(.0847)\end{array}$ & $\begin{array}{l}0.0010 \\
(.0874)\end{array}$ \\
\hline Year & $\begin{array}{c}0.0349 * * * \\
(0.0111)\end{array}$ & $\begin{array}{c}0.2134 * * * \\
(0.0479)\end{array}$ & $\begin{array}{c}0.2255 * * * \\
(0.0712)\end{array}$ \\
\hline Year Square & - & $\begin{array}{c}-0.0062 * * * \\
(0.0016)\end{array}$ & $\begin{array}{l}-0.0077 \\
(0.0069)\end{array}$ \\
\hline Year Cube & - & - & $\begin{array}{l}0.0001 \\
(.0002)\end{array}$ \\
\hline Constant & 6.5549 & 21.1086 & 20.7438 \\
\hline $\mathrm{N}$ & 202 & 202 & 202 \\
\hline
\end{tabular}

Note: Values in parenthesis are standard errors. *Significant at 10 percent; ** Significant at 5 percent; and $* * *$ Significant at 1 percent.

${ }^{+}$Unemployment rate is not transformed to logarithmic form. 
Table 5: Estimated growth/forecasted model for tax receipts (1995-2010) using fixed effect (state) in semi-log specification with Slots and Tables in the model.

\begin{tabular}{|c|c|c|c|}
\hline Variable & $\begin{array}{l}\text { Fixed Effect } \\
\text { (State) (1) }\end{array}$ & $\begin{array}{l}\text { Fixed Effect } \\
\text { (State) (2) }\end{array}$ & $\begin{array}{c}\text { Fixed Effect } \\
\text { (State) (3) }\end{array}$ \\
\hline Establishment & $\begin{array}{c}0.0289 * * \\
(0.0144)\end{array}$ & $\begin{array}{c}0.0206 \\
(0.0145)\end{array}$ & $\begin{array}{c}0.0232 \\
(0.0147)\end{array}$ \\
\hline Establishment Squared & $\begin{array}{c}-0.0002 * * \\
(0.0001)\end{array}$ & $\begin{array}{l}-0.0001 \\
(0.0001)\end{array}$ & $\begin{array}{l}-0.0001 * \\
(0.0001)\end{array}$ \\
\hline Unemployment Rate $^{+}$ & $\begin{array}{l}-0.0118 \\
(0.0318)\end{array}$ & $\begin{array}{l}-0.0265 \\
(0.0317)\end{array}$ & $\begin{array}{l}-0.0271 \\
(0.0318)\end{array}$ \\
\hline Real State Product & $1.9626 * * *$ & 0.0317 & 0.2063 \\
\hline Per-capita & $(0.6692)$ & $(0.0318)$ & (1.1988) \\
\hline Tables & $\begin{array}{c}0.3053 \\
(0.2614)\end{array}$ & $\begin{array}{c}0.2158 \\
(0.2583)\end{array}$ & $\begin{array}{c}0.1871 \\
(0.2599)\end{array}$ \\
\hline Slots & $\begin{array}{l}-0.1903 \\
(0.3078)\end{array}$ & $\begin{array}{l}-0.1604 \\
(0.3008)\end{array}$ & $\begin{array}{l}-0.1643 \\
(0.3008)\end{array}$ \\
\hline Recession Dummy & $\begin{array}{l}-0.2198 \\
(0.1421)\end{array}$ & $\begin{array}{l}-0.1010 \\
(0.1484)\end{array}$ & $\begin{array}{c}-0.0647 \\
(-0.0647)\end{array}$ \\
\hline Year & $\begin{array}{c}0.0222 \\
(0.0230)\end{array}$ & $\begin{array}{c}0.2471 * * \\
(0.1019)\end{array}$ & $\begin{array}{c}0.3261 * * \\
(0.1285)\end{array}$ \\
\hline Year Square & - & $\begin{array}{c}-0.0073 * * \\
(0.0032)\end{array}$ & $\begin{array}{l}-0.0187 \\
(0.0118)\end{array}$ \\
\hline Year Cube & - & - & $\begin{array}{c}0.0004 \\
(0.0004)\end{array}$ \\
\hline Constant & -1.3368 & 19.9057 & 16.2214 \\
\hline $\mathrm{N}$ & 100 & 100 & 100 \\
\hline
\end{tabular}


Table 6: Estimated growth/forecasted model for tax receipts (1995-2010) using fixed effect (state) in semi-log specification with slots, tables and average tax rate for four states

\begin{tabular}{l|c|c|c}
\hline Variable & $\begin{array}{c}\text { Fixed Effect } \\
(\text { State })(1)\end{array}$ & $\begin{array}{c}\text { Fixed Effect } \\
(\text { State })(2)\end{array}$ & $\begin{array}{c}\text { Fixed Effect } \\
(\text { State })(3)\end{array}$ \\
\hline Establishment & \\
& $0.2618^{* * *}$ & $0.1627^{*}$ & 0.1338 \\
Establishment & $(0.0802)$ & $(0.0899)$ & $(0.0853)$ \\
Squared $^{+}$ & $-0.0091^{* * *}$ & $-0.0054^{*}$ & -0.0043 \\
Unemployment Rate $^{+}$ & $(0.0029)$ & $(0.0032)$ & $(0.0031)$ \\
& -0.0271 & -0.0223 & $-0.0395^{* *}$ \\
Real State Product & $(0.0205)$ & $(0.0198)$ & $(0.0198)$ \\
Per-capita & $2.6303^{* * *}$ & $1.8342^{* * *}$ & $1.4516^{* *}$ \\
Tables & $(0.4895)$ & $(0.5987)$ & $(0.5820)$ \\
& -0.1793 & 0.1139 & 0.1102 \\
Slot & $(0.2008)$ & $(0.2364)$ & $(0.2225)$ \\
& 0.0713 & -0.1225 & -0.1285 \\
Average Tax & $(0.1493)$ & $(0.1622)$ & $(0.1527)$ \\
& $-1.0092^{* * *}$ & $-0.9254^{* *}$ & $-0.9766^{* * *}$ \\
Recession Dummy & $(0.3634)$ & $(0.3523)$ & $(0.3321)$ \\
& 0.0062 & -0.0049 & -0.0126 \\
Year & $(0.0609)$ & $(0.0589)$ & $(0.0555)$ \\
& $0.0334^{* * *}$ & $0.1499^{* * *}$ & $0.3823^{* * *}$ \\
Year Squared & $(0.0083)$ & $(0.0545)$ & $(0.1022)$ \\
& - & $-0.0051^{* *}$ & $-0.0322^{* * *}$ \\
Year Cube & & $(0.0023)$ & $(0.0105)$ \\
& - & - & $0.0009^{* * *}$ \\
Constant & & & $(0.0003)$ \\
$\mathrm{N}$ & -5.2763 & 3.0124 & 6.9699 \\
\hline
\end{tabular}

Note: Values in parenthesis are standard errors. *Significant at 10 percent; ** Significant at 5 percent; and $* * *$ Significant at 1 percent.

${ }^{+}$Unemployment rate is not transformed to logarithmic form. 
Table 7: Aggregated gross revenue for Illinois casinos (\$, Million)

\begin{tabular}{c|c|c}
\hline Year & $\begin{array}{c}\text { Gross } \\
\text { Revenue }\end{array}$ & $\begin{array}{c}\text { Revenue per } \\
\text { establishment }\end{array}$ \\
\hline 1991 & 14.94 & 0.04 \\
1992 & 226.33 & 0.64 \\
1993 & 605.68 & 1.55 \\
1994 & 979.55 & 2.43 \\
1995 & 1178.31 & 2.77 \\
1996 & 1131.49 & 2.50 \\
1997 & 1054.57 & 2.34 \\
1998 & 1106.75 & 2.45 \\
1999 & 1362.93 & 2.76 \\
2000 & 1658.00 & 2.93 \\
2001 & 1783.96 & 2.94 \\
2002 & 1831.55 & 3.54 \\
2003 & 1709.94 & 3.22 \\
2004 & 1717.99 & 3.11 \\
2005 & 1798.91 & 3.14 \\
2006 & 1923.53 & 3.38 \\
2007 & 1983.39 & 3.87 \\
2008 & 1568.73 & 3.09 \\
2009 & 1428.92 & 2.66 \\
2010 & 1373.42 & 2.46 \\
\hline
\end{tabular}

Source: Illinois Gaming Board 
Table 8: Estimated growth/forecasted model for Illinois's tax receipts using semi-log specification.

\begin{tabular}{l|c|c|c}
\hline Variable & $\begin{array}{c}\text { Illinois and Iowa } \\
\text { in the model }\end{array}$ & $\begin{array}{c}\text { After Missouri } \\
\text { opened casinos in } \\
1992\end{array}$ & $\begin{array}{c}\text { After Indiana } \\
\text { opened casinos in } \\
1995\end{array}$ \\
\hline Establishment & $5.7325^{* * *}$ & $5.3590 * * *$ & $5.4431^{* * *}$ \\
Unemployment rate ${ }^{+}$ & $(0.3725)$ & $(0.3506)$ & $(0.3425)$ \\
Real State GDP Per- & 0.0432 & 0.0225 & 0.0374 \\
capita & $(0.0339)$ & $(0.0300)$ & $(0.0307)$ \\
Time & $(0.7575 * * *$ & $1.8554 *$ & $1.7326 *$ \\
Iowa & -0.0365 & $(0.8839)$ & $(0.8548)$ \\
Missouri & $(0.0221)$ & -0.0257 & -0.0284 \\
& 0.0395 & $(0.0193)$ & $(0.0187)$ \\
Indiana & $(0.0274)$ & 0.0268 & 0.0289 \\
Constant & - & $(0.0239)$ & $(0.0230)$ \\
Adj-r & & $0.0633 * *$ & 0.0378 \\
$\mathrm{~N}$ & - & $(0.0252)$ & $(0.0301)$ \\
\hline
\end{tabular}

Note: Values in parenthesis are standard errors. * Significant at 10 percent; and ${ }^{* * * S i g n i f i c a n t}$ at 1 percent. ${ }^{+}$Unemployment rate is not transformed to logarithmic form. 
Figure 1: Casino gross revenues (\$, million).

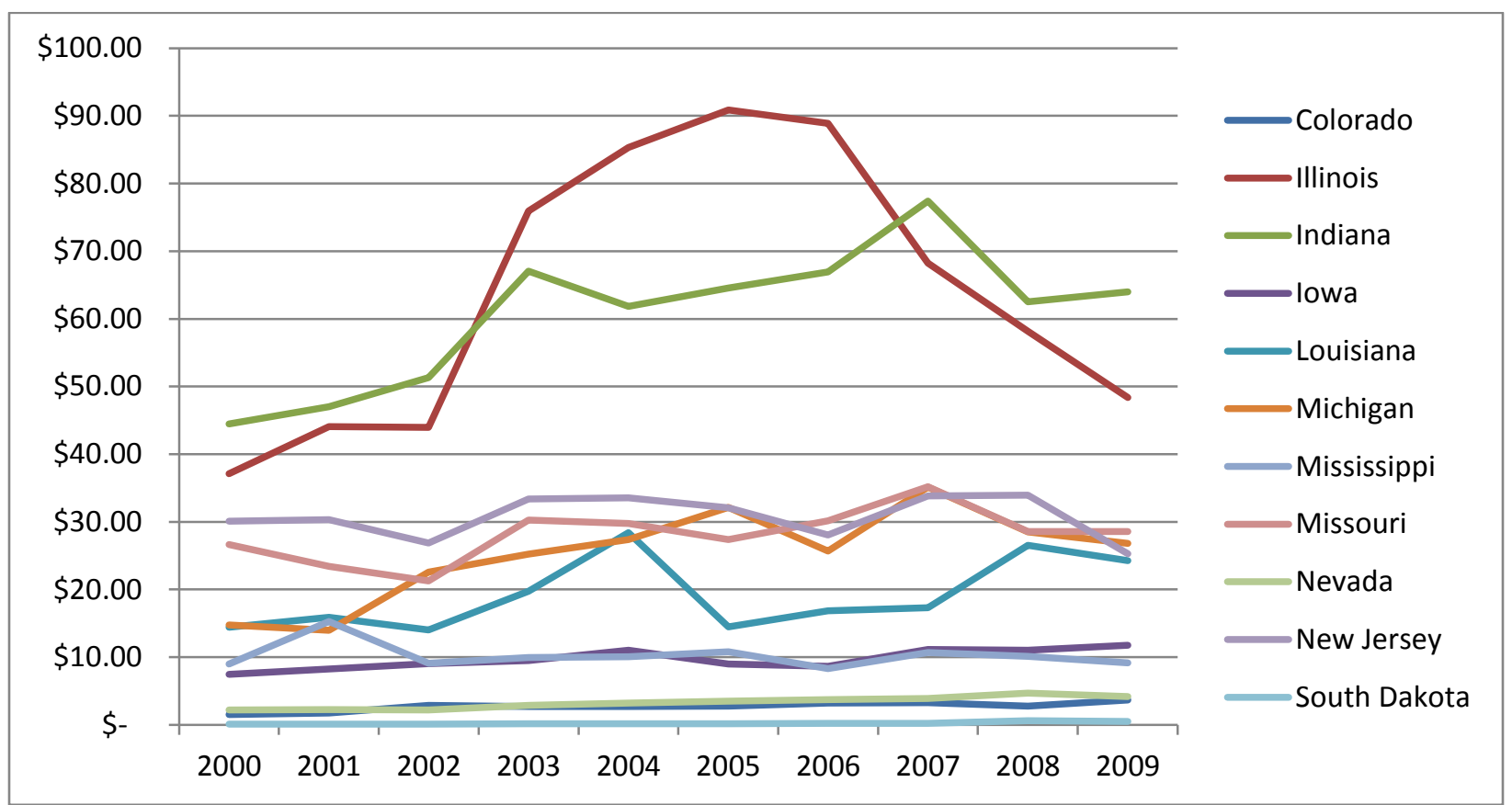

Source: Dadayan and Ward and state gaming commission reports.

Figure 2: Casino gross revenues percentage change per establishment per year.

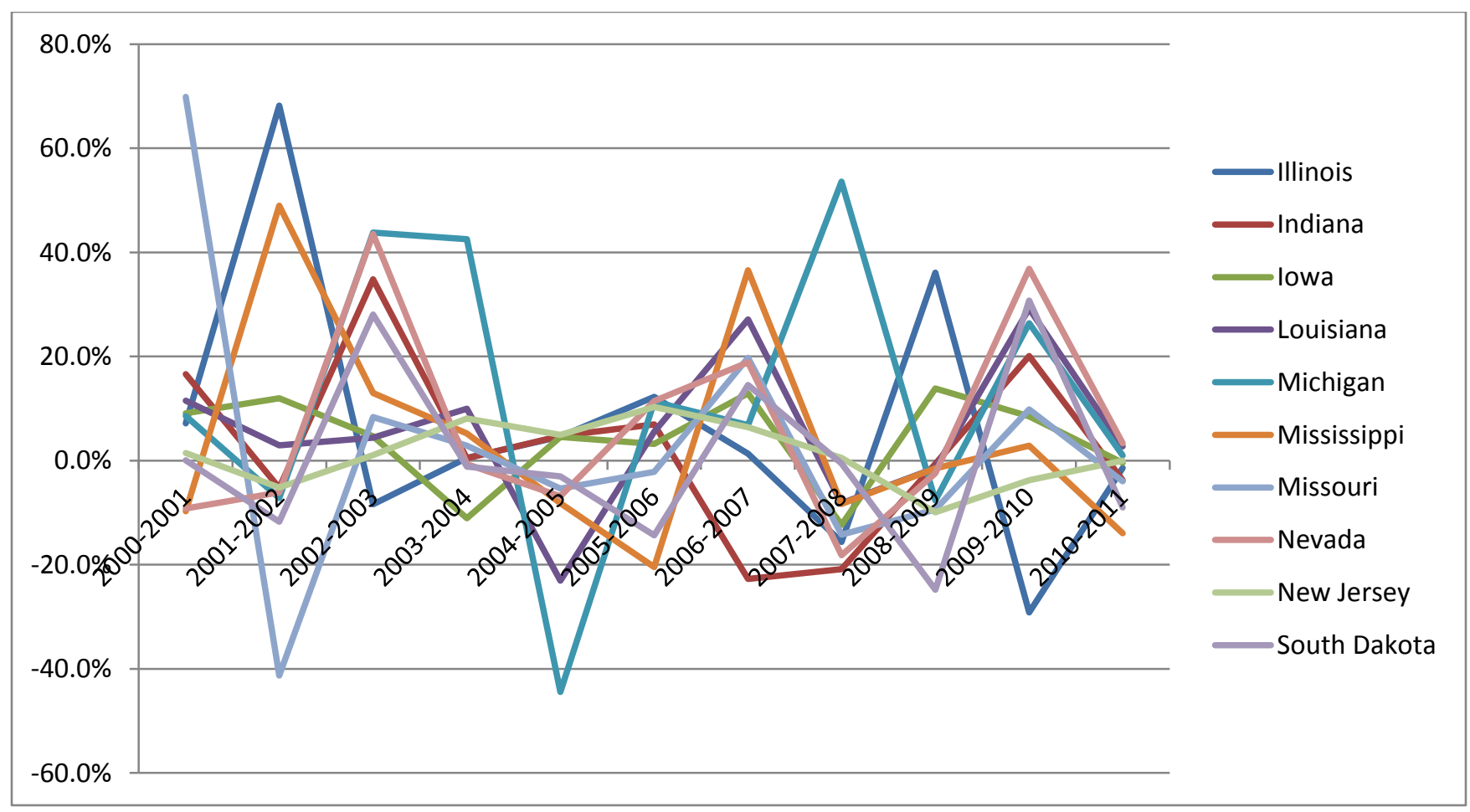

Source: Dadayan and Ward and state gaming commission reports. 
Figure 3: State and local government tax revenues from casino operations, Fiscal Years, 2000-2010.

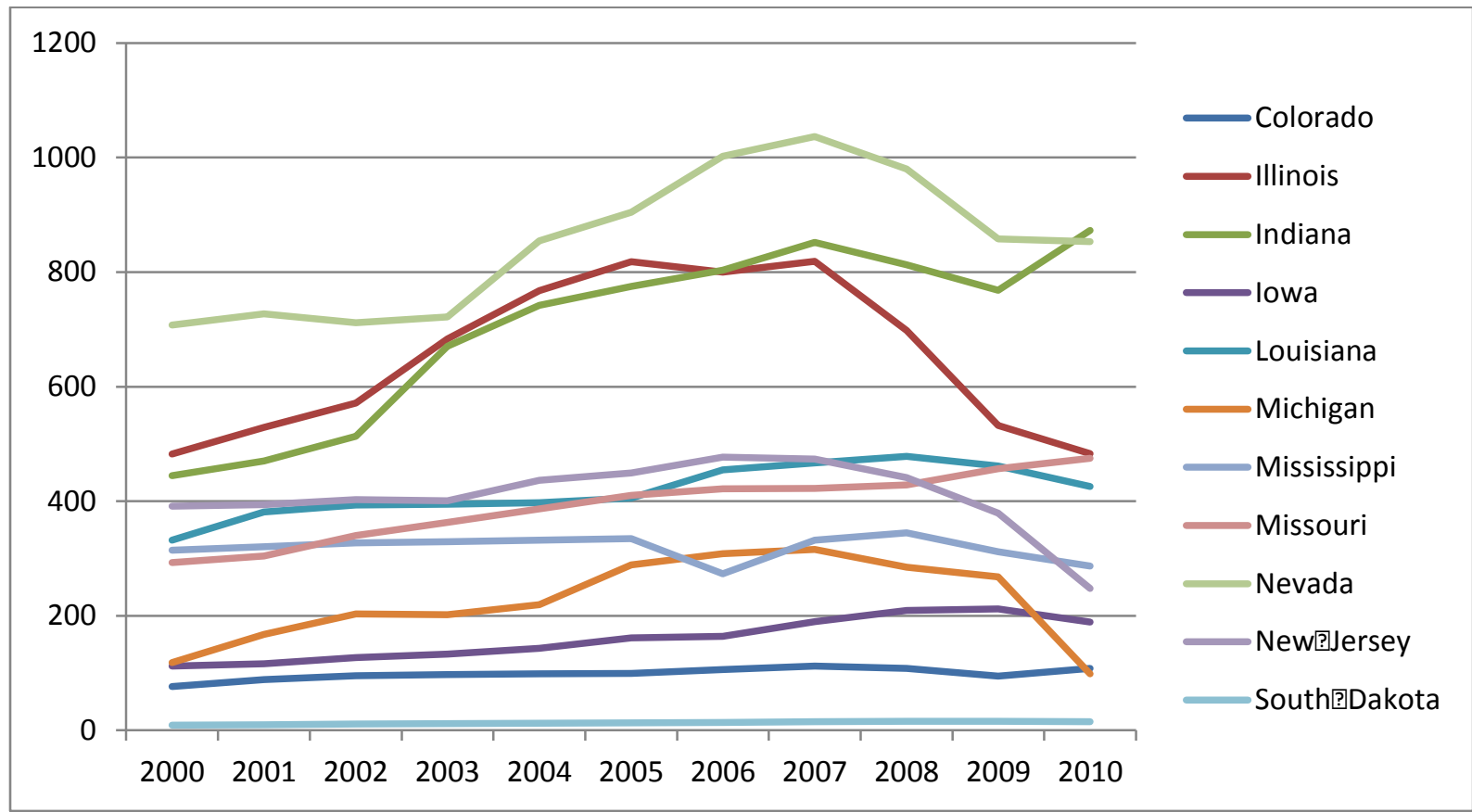

Source: State gaming commission reports.

Figure 4: State and local tax revenue percentage change per establishment per year.

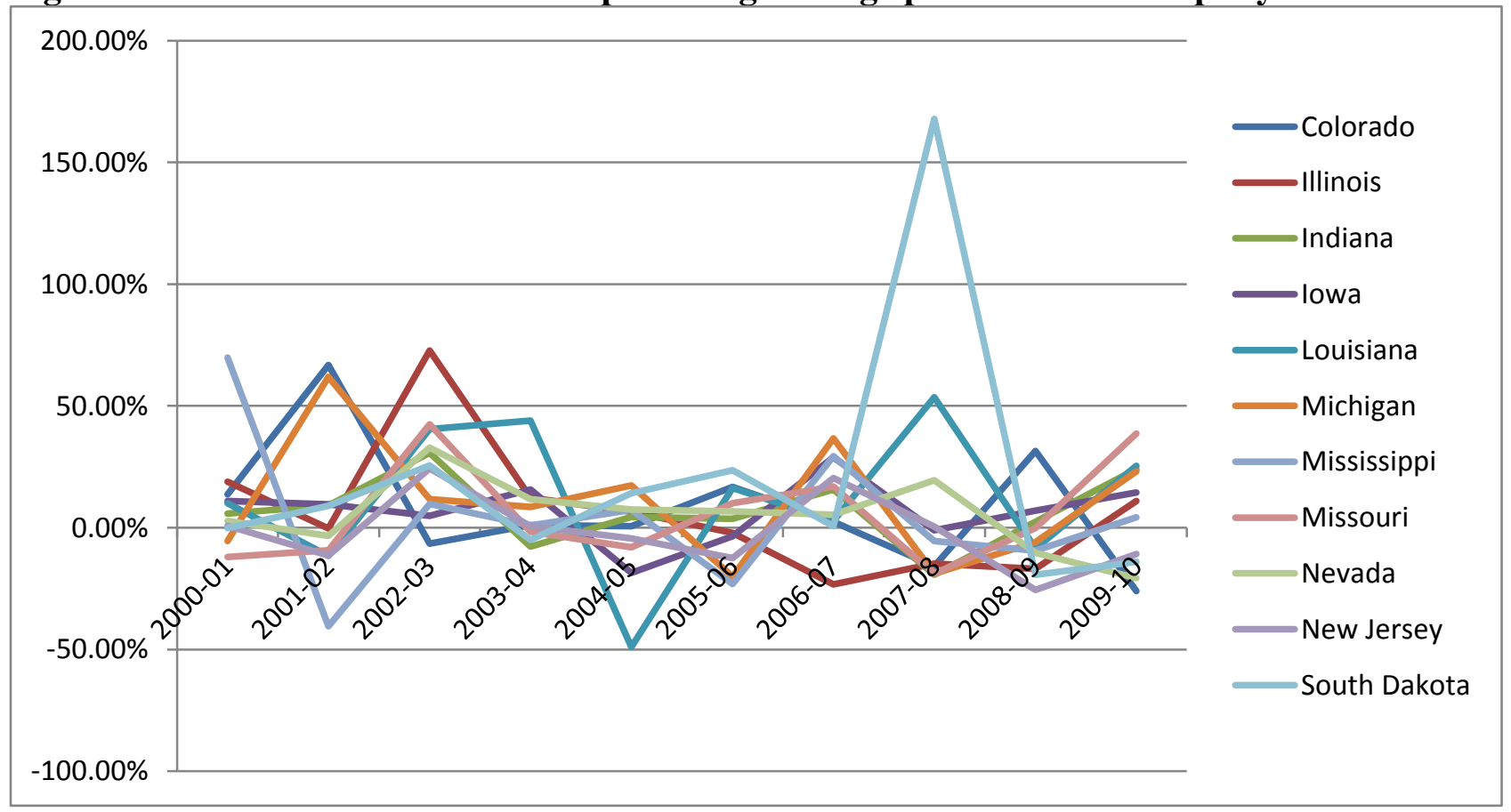

Source: State gaming commission reports. 


\section{Appendix}

Table 1: Estimated growth/forecasted model for tax receipts (2001-2010) with Native American casinos using a fixed effect model

\begin{tabular}{|c|c|c|}
\hline Variable & $\begin{array}{c}\text { Fixed Effect } \\
\text { (State) }\end{array}$ & $\begin{array}{c}\text { Fixed Effect } \\
(\text { State })\end{array}$ \\
\hline Establishment $^{+}$ & $0.0084 * *$ & $0.0070^{* *}$ \\
\hline Establishment & $(0.0035)$ & $(0.0035)$ \\
\hline Squared $^{+}$ & $\begin{array}{c}-0.00001 * * \\
(0.0000)\end{array}$ & $\begin{array}{c}-0.00001 * \\
(0.0000)\end{array}$ \\
\hline Unemployment Rate $^{+}$ & $\begin{array}{c}-0.0132 * \\
(0.0068)\end{array}$ & $\begin{array}{c}-0.0146 * * \\
(0.0067)\end{array}$ \\
\hline Real State Product & $0.9037 * * *$ & 0.5002 \\
\hline Per-capita & $(0.2775)$ & $(0.3329)$ \\
\hline Native American & $-0.0380 *$ & $-0.0499 * *$ \\
\hline Casino & $(0.0196)$ & $(0.0200)$ \\
\hline Recession Dummy & $\begin{array}{c}-0.0089 \\
(0.0246)\end{array}$ & $\begin{array}{c}0.0119 \\
(0.0261)\end{array}$ \\
\hline Year & $\begin{array}{c}0.0163 \\
(0.0037)\end{array}$ & $\begin{array}{c}0.1369 * * \\
(0.0573)\end{array}$ \\
\hline Year Square & - & $\begin{array}{l}-0.0037 \\
(0.0261)\end{array}$ \\
\hline Constant & -21.29 & -257.90 \\
\hline $\mathrm{N}$ & 110 & 110 \\
\hline
\end{tabular}

Note: Values in parenthesis are standard errors. *Significant at 10 percent; $* *$ Significant at 5 percent; and $* * *$ Significant at 1 percent. ${ }^{+}$Unemployment rate, Establishment and Native American Casino are not transformed to logarithmic form. 